\title{
An Analysis of the Controlling Function of National Culture in Product Choice Preferences of Japanese Consumers
}

\author{
L. Chamila Roshani Perera \\ Kobe University \\ E-Mail: Chamilaroshini2004@yahoo.com \\ Chandana Rathnasiri Hewege \\ Monash University \\ E-Mail: chandana.hewege@buseco.monash.edu.au
}

\begin{abstract}
The aim of this paper is to analyse the controlling function of national culture in regulating product choice behaviour of consumers. Japanese consumers showed signs of a high culture enabling remarkable economic achievements during 70's and 80's. Nationalistic feeling coming from this high culture initially favoured indigenous products creating a natural control of the influx of foreign products to the country. However, with the dilution of indigenous nature of culture, product preferences have begun to incline towards western products in general with marked preference toward American products. The study investigates the controlling function of national culture on consumer product preferences relating to local products and products of western origin. The paper reviews socio-economic developments that cause changes in product choice behaviour and the process of western influence on the Japanese culture. The methodology used in the study is qualitative and it includes case analyses of individuals' purchase preferences. In-depth interviews were conducted to unearth dynamics caused by cultural change and control function of the national culture affecting product choice behaviour. The study illustrates as to how national culture controls product choice preferences of Japanese consumers relating to Western products. The main implication is that by changing core values of national culture, product preferences relating to foreign products can be regulated and controlled.
\end{abstract}

Keywords: Japanese Consumer Preferences, National Culture, Controlling Function of Culture 


\section{INTRODUCTION}

Numerous factors account for the changes in product choice behaviour of consumers. Apart from utilitarian motives, complexes of other socio-cultural factors influence the product choices and preferences of consumers. Culture is one of the key elements of product choice determinants of the consumers and national culture is gaining importance in marketing as a general theory (Clark, 1990). Products are significations of values, attitudes, norms and cultural symbols. Culture as an antecedent for consumer behaviour has received immense attention from researchers (for example, Elinder 1961; Fatt 1964; Levitt 1983; Ohmae 1985; Roostal 1963; Douglas and Craig 1992). National culture forms a country's unique identity and it tends to regulate consumers' attitudes toward both domestic and foreign products (Netermeyer et al., 1991).

Japanese national culture has been the subject for many studies concerning Japanese economic miracle during the period between $70 \mathrm{~s}$ and $80 \mathrm{~s}$ and many studies attempted comparative assessments of both Japanese and American national cultures (For example; Deshpande, Farley, and Webster 1993). For consumers in developed countries, research has consistently found that there is a preference for products manufactured in their home country (Bilkey and Nes, 1982; Rierson, 1967; Samiee.1994). Consumers from strong cultures (nationalistic) tend to prefer domestic products to foreign products. This phenomenon is often referred to as consumer nationalism. Shimp and Sharma (1987) found that consumer nationalism is negatively correlated with purchase of foreign products.

However recent studies indicate that there is a tendency toward westernization of Japanese consumer behaviour characterized by increased affluence, widespread ownership of western products, an increased number of women working outside home, and an emphasis on convenience, fashion and leisure (Dentsu, 1988; Johannson, 1986; Roth 1995). Moreover, instead of being a mere determinant of purchase behaviour, national culture tends to perform a controlling function of the buyer choices by regulating the consumer attitudes, values and norms. National culture has controlling effect over constituents of a society both collectively and individually. Changes in the fundamental character of the national culture over time are bound to control the product choice preferences of the consumers. However, the controlling function of Japanese national culture over the product choice behaviour of Japanese consumers has received relatively little attention. More importantly, in the context of cultural control of purchase behaviour, 
an analysis as to how product choice behaviour changes with the westernization of Japanese culture is significant. This paper aims to shed some light on this phenomenon.

In the next section, a review on influences of Socio-economic changes on product choice behaviour is presented followed by the aspects of national culture that shape consumer product choice preferences in the second section. The third section specifically discusses about the process of westernization weakening Japanese culture. Then, the methodology used in the study is explained. In the fifth section, the paper illustrates the individual cases and qualitative analysis followed by managerial implications and concluding comments in the final section.

\section{INFLUENCE OF SOCIO-ECONOMIC CHANGES ON PRODUCT CHOICE BEHAVIOUR}

During the period of rapid economic growth, Japanese consumers responded to product differentiation favourably. Consumers did not resist high prices and they were also prepared to pay extra for subtle improvements in product features. The rapid economic growth of the 70s-80s slowed in 1990s. Japan faced an explosion of its economic "bubble" in 1991. Japanese consumer behaviour has considerably been affected by major changes in economic and social environment characterized by continuous recession, growing numbers of bankruptcies, rising unemployment, slumping stock market and erosion of basic certainties such as lifetime employment, and the continuously rising cost of living. Consumers have experienced major reductions in their income in terms of yearly bonuses and overtime work. As a result, consumers have learned to be price conscious. Moreover, after the oil crisis, during the 70s, consumer response to product differentiation deteriorated. With the erosion of real income due to high inflation, consumers became more price conscious. Many studies (for example; Kajihara, 1990) showed that consumers tend to be independent of firms' marketing actions. Consumers were forced to change their purchasing behaviour by rapid inflation after the oil crisis. Further, according to the nationwide survey (Kajihara, 1990) on changes in consumer reaction to prices, products and stores after the oil crises, it was found that consumers in Japan were more responsive to product differentiation, lot of repeated advertising and store differentiation. This made consumers stick to specific brands. However he also found that those characteristics of consumer behaviour had been rapidly weakened by the inflation. There was a tendency for consumers to show more interest in prices and less interest in product differentiation. Reduction of real value of 
money, "workaholic" nature and long-term commitments led consumers to seek economy and convenience. An increase in convenience stores has been reported in Japan (Hakuhodo Institute of Life and living, 1988) and the convenience store business is promising, continually growing for more than 20 years, outrunning the supermarkets, department store and discount store firms (Ogawa, 1988).

Japanese culture was undoubtedly the cornerstone of economic stability over the years. However, the harmonious relationship between culture and economy has become broken as a result of the aforementioned developments over the past few years. With these changes, Japanese cultural values have undergone a significant turn as culture and economic activities are interwoven. For example, in Marxian theory as well as Antonio Gramsci's theory of hegemony, there is a vivid analysis of the ways in which cultural and political processes affect economic relations and vice versa (Swanson J, 2005). This is further highlighted:

"Culture and economy are thoroughly imbricated with one another...even our core economic practices have a constitive, irreducible cultural dimension; shot through to the core with significations and Norms, they affect not only the material well-being of social factors, but their identities and status as well" (Swanson J, 2005).

According many studies about Japan's recent history, there are four main periods; Pre-war period, War-time, post-war and high-growth period. The pre-war and war-time periods are seen as dark eras. The post-war and high-growth periods were eras of manly men. Studies on this recent history 1970's and 1980s are described as an era of individualism and feminism. The studies also emphasize the wreaking of the group behaviour, which once was considered as a core Japanese value. Furthermore, the images of men, women, and children changed as markets evolved. The role of a man was seen as "husbands should be healthy and out of the house" (McCreery J, 2000). However, in contrast to the man's image depicted in studies, the image of a woman became increasingly that of an independent one. Studies in this context have emphasised on an evolution from primary image of women to housewife to mother to liberated woman. This evolution does not only imply increasing freedom for women but also an increasing concern for style and sexual appeal in the image that they present to others. The Japanese have historically been considered as different and unique. The acceptance of authority is well embedded in their society that is hierarchical. 
It is apparent that the changes in the economic conditions over a period of time have influenced the pattern of consumer behaviour. This influence in product choice behaviour is indirect as economic changes first affect culture and then through culture it influences purchase behaviour. Dilution of brand and product loyalty with the erosion of real value of money due to inflation has been the predominant factor that has shaken the strong attachment to quality and brand name. Movement from traditional society to a modern society has been one of the major factors changing culture that intern regulates purchase preferences of consumers. Traditional culture and its values (representing a high culture) are likely to wither with the Westernization of the cultural values (representing a low culture).

\section{SOME ASPECTS OF JAPANESE NATIONAL CULTURE SHAPING CONSUMER PRODUCT CHOICE PREFERENCES}

Consumers satisfy their needs and wants using products. The term "product" means any thing that can satisfy a consumer's need. In this study the researchers use the term product encompassing the idea of physical products, services, organisations, people, occasions, events, experiences or ideas that could satisfy a human need or want. A consumer passes through three stages in choosing a product for satisfaction; prepurchase, consumption and post consumption. The consumer makes several choices in selecting, buying, using, and disposing products, services, ideas or experiences. In simple terms, a choice or a decision is the selection of an option out of two or more alternatives; e.g. whether to buy a pen or pencil; brand, A or B. Or else, it may be a choice of whether to buy a local brand or an international brand. Product choice is influenced by many factors internal and external to consumers. Certain product choices require a high involvement from the consumer whereas others require a low involvement. The intensity of information processed by consumers varies according to the product they choose.

Culture signifies values, beliefs, attitudes and norms that are commonly shared among a group of inhabitants in a society (Hofstede, 1980; Hall \& Hall, 1990). National culture is the "software of the mind" that regulates or controls all other behavioural intensions that originate in the human mind. This "software" may change from time to time with the pressures coming from outside or from inside. Sometimes, it is necessary to change the culture to regulate behaviour of a group of people in a society (some multinationals are reported to have attempted to change national cultural values of countries to control and regulate purchase behaviour of people). However, it is not an 
objective of this paper to assess various opposing views about national cultures. The controlling role of culture is the key aspect that is given attention. The meaning of the terms "high cultures" and "low cultures" are important. A high culture is more introvert, cohesive, closely knitted, convergent, resisting change and rejects alien and foreign influence. A high culture favours what is produced within the culture and has a repulsive feeling toward practices coming from other cultures (E.g. product from other countries). On the other hand, a low culture is a loosely bound, flexible, extrovert, and adaptable one. It favours what is functional and utilitarian irrespective of the fact that the products come from other cultures. The change of cultural values from high to low culture is certain to change the product choice preferences of consumers. A high culture that does not favour products from country (A) can be influenced to accept country (A)'s products by changing core cultural values of this high culture. This is the regulatory or controlling function of a culture. By controlling or regulating the culture, marketers can control behaviour of consumers.

Culture manifests through language, knowledge, laws, religions, food and food habits, customs, music, art, technology, work patterns and behaviour, products and many other artefacts. Ahmed and Krohn (1992) examined the unique cultural characteristics of the behaviour of Japanese tourists visiting USA. They cited ten major elements in Japanese culture which influence purchase behaviour; belongingness, family influence, empathy, dependency, hierarchical acknowledgement, propensity to save, the concept of kinen (collecting evidence), tourist photography, passivity and risk avoidance.

Japanese consumers spend a relatively longer time than Western customers do in decision making. They make purchase decisions in a shorter time. In addition, they endeavour to avoid situations that offend and disturb the harmony of the group (ZiffLevine 1990). The risk avoiding trait of Japanese consumers leads them to generate several alternatives, compare and evaluate them and process large amount of information. Similarly Japanese consumer evaluates product-related information via various sources, formal and informal. At the same time they concern about others' choices and try to comply with them as it ensures the harmony with the group.

Recently, homogeneous shopping habits of Japanese have begun to change due to many factors (Brown, 1996). As a result, heterogeneous shopping groups began to emerge. For example, with regard to the preference for shopping malls, Japanese teens tend to view shopping malls in the same way that American teens view shopping malls. The shopping malls in this category are functionally similar to the prototypical American 
malls (Parker, R S., Herman, C M., and Schaefer, A D.2004).

Hofstede (1991) found that Japan's national culture differs from that of the US along five dimensions, Individualism /Collectivism, uncertainty avoidance, and high/low context. The collectivism in Japanese culture manifests in wide range of business strategies and practices and social norms. Industrial groups (collectivism) such as "keiretsu" (Gerlach, 1992) were considered as a main impediment to a foreign firm entering in to Japanese market. Japanese society gives primacy to societal interest over individual interest. Extended families were a common phenomenon in the past. The members of the society were well knitted together. But today small nuclear families are common and as a result of this there is a child centred mentality among Japanese parents. White (1993) found that many Japanese mothers work part time and incur heavy debts so as to provide their children with luxury items.

Japanese are extremely risk-aversive as a society (Hofstede 1991). They avoid conflict, competition, and risk taking to ensure social harmony. Japanese businesses minimize the risk of doing business with unfamiliar vendors or customers by forming long-lasting business relationships that are characterized by high level of trust (Sullivan and Peterson 1988). Japanese culture is a high power-distant culture with due recognition to authority, supervision and hierarchy (Hofstede, 1980). According to Hall and Hall (1987), Japan is a "high-context" culture in which the social and temporal context of communications is key to understanding the meaning intended by the content or words of the messages. On the other hand the Japanese are extremely keen on detail, aesthetics, quality and service (Turcq and Usunier, 1985). Who says it and when, how and where it is said can be more important than what is said in high context. According to Hall (1976), in a high context culture the meaning of information received is implied through nonverbal cues and it further depends on the situation and personal relationships. In low context cultures such as USA, accurate communication does not depend much on longstanding personal relationships or other contextual factors (Money, B R, Gilly, C M, Graham, L J. 1998).

\section{PROCESS OF WESTERNIZATION: WEAKENING THE HIGH CULTURE}

The Japanese consumers were able to maintain their unique identity by controlling their interactions with the rest of the world. On the one hand, Japan sustains its markets efficiently through many tariff and non-tariff barriers and business practices. The "ways of doing business" in Japan is outlined and framed by many laws and regulations which 
are well strengthened by their unique cultural values. On the other hand, over the years, though many new food products were introduced, Japanese consumers did not easily adopt them. They were able to remain homogeneous over a long period of time. However, according to recent studies, Japanese have appeared to embrace many new fashions, tastes, products, beliefs and values etc. from the West. In the past, Japanese usually absorbed new fashions or values that were consistent with their fundamental beliefs and discarded the rest. This process enabled them to maintain their homogeneity and core values while adapting to a dynamic environment. It is reported that 20-24 and 25-29 age groups taken together form the second largest group of females in the work force (Social Indicators 1997). Significantly, the strong liking toward indigenous products has diluted and consumer preference for western products has become strong. Furthermore, Shimp and Sharma (1987) found that younger consumers tend to be less nationalistic.

Japanese have been well known for their strong sense of economic nationalism. Influence of Confucian teachings has created nationalist values such as readiness to sacrifice for the good of the nation. Coming from this sense of conformity, it is not uncommon to note that there is a very minimal level of consumer movements in Japan. Further, around the mid sixteenth century Japanese people were grouped into four social classes as in order of rank warriors (samurai), farmers, artisans, and merchants (Sansom, 1931). Samurai tradition requires Japanese not to question the authority and government.

People are grouped by age in categories referred to as "sedai" in Japanese (Shin S,Gehrt K, and Lotz S., 2001). Sedai has played a new role in Japanese society in recent years due to the significant social and cultural changes occurred during the post-war period of economic growth. A major event was the pursuit of an American or western style. This influenced each post-world war generation in its own unique manner (Shin S, Gehrt K, and Lotz S., 2001). According to Itochuo Fashion system Corporation (1998) classification of Japanese sedai consists of Dankai Sedai (49-54 years old), DC Brand Sedai (42-48 years old), Hanako Sedai (36-47 years old), Banana Sedai (30-35 years old), Dankai junior Sedai (24-29 years old) and Pokeberu Sedai (20-24 years old).Of the six groups the dankai junior (24-29) generation is thought to be among the most distinctive in the consumption behaviour (Shin S,Gehrt K, and Lotz S.,2001). Dankai Sedai is the baby boomers or bulge generation in Japan. Itochuo Fashion system Corporation (1998) characterized this generation as contributors for Japanese economic growth, exposure to US-style consumption/Mass consumption and affluent silver (grey) 
market. Dankai juniors who form the core of Japanese culture were born in the affluent post-war society when Japan was perceived as emerging economic power. They tend to influence greatly their family purchase decisions. Dankai Sedai are strong followers of the unique Nationalistic Japanese consumer culture. However the younger generations, Banana, Dankai junior and Pokeberu display a low level of involvement, are westerninfluenced and display individualistic characteristics (Shin S, Gehrt K, and Lotz S., 2001).

Westernization influence on Japanese culture involves in changing the core values to lighten the "closely knitted" traditional culture. Westernization is mainly seen as Americanisation. Indigenous orientation of the culture takes a turn to accept and acculturate American values that enable Japanese consumers to prefer products of western origin. The change of the "software" of the mind is about changing the metal programming. The process of westernization has evolved over a period of time. The variety of products available today either foreign branded or domestic was a miracle in the past. Currently, Japan is the largest and the most important single source of International tourists to Australia representing 21\% of all international visitors (Bureau of Tourism Research, 1996). Foreign travel has made consumers aware of other product options. The main reason for Japanese to travel abroad is to experience Western civilization (Hendry, 1987; Leiper, 1985, 1987; Zimmerman, 1985). However, their embedded values such as not questioning authority and hierarchy made it difficult to convert product knowledge into consumer purchase behaviour. At the same time foreign investors began to enter in to the Japanese market with competitive marketing strategies. One of the easiest ways to enter in to a market is to target innovators and early adaptors. The baby busters and Japanese yuppies were the easiest. They have not experienced the war or struggling economy immediately after the war. They are the "blessed generation" that harvest what their elders developed. Teenagers value fashion perhaps more than any other group (Koester and May 1985). They also value the internet, mobiles and satellite television (Meredith and Schewe, 2002). Wysocki (1997) suggests international communication modes such as internet chat rooms, and other international programs homogenize teen preferences and attitudes. The expansion of global connectivity has increased the similarity between teens in different countries compared to between teens and older persons in the same country (Anderson and Hee, 1998). This force has also brought about a convergence of global teen values such as independence, self expression, openness to new ideas and cultures, flexibility, mobility, and enjoyment of life (Meredith 
and Schewe, 2002). Japanese cultural values are increasingly being influenced by these developments. Although Japan has a relatively small number of teenagers, in aggregate, they rank as the fourth highest spending teenage market in the world (Krauss.2001). Given this scenario, international marketers devise strategies to change the way of thinking, values, and beliefs of consumers and as a result the change in the culture occurs affecting product choice behaviour.

Acculturation is common to any nation or society where the members belong to one culture learn or adopt another culture. It is not difficult to identify acculturation effect to a country. For example, in a modern wedding ceremony in Sri Lanka, one can easily understand that "pooruwa ceremony" (a wedding day ritual) as real artefact of Sri Lankan culture. But, when the newly married couple cut the wedding cake, it is a symbol of assimilation of Western Culture. However, in the case of Japanese consumers, it is very difficult to distinguish some acculturation practices as they are very well blended with Japanese Culture. The following quote elaborates:

"Foods once marked as foreign are being domesticated by young Japanese; perhaps by the turn of the century spaghetti and hamburgers will have lost all traces of their foreign origins. Signs of the domestication of the hamburgers can be seen in its inclusion (without bun) in the "okosama teishoku (the special children lunch) served in department store restaurants and in the success of McDonald's Japan, whose Biggu Makku and Makku-fuai (French fries) have become so thoroughly a part of Japanese life that Japanese tourist in Waikiki and Paris wait in line to order them when they are feeling homesick and want to eat something familiar" (Tobin, J J., 1992).

The product choice behaviour of Japanese has changed with the inclusion of western products in the shopping basket. Interestingly, one can easily notice the Japanese consumption transition from "Nihoncha" (Japanese tea) to coffee, fish to meat, silk to synthetics, Kimono to western clothing, rice to wheat, tatami to carpet, and traditional Japanese wooden house to western house models, sake to whiskey or beer and extended household to single family pattern. The common perception of a "Japanese" is as an "imitator" not as a "creator". In the early period of development, the key to strategy was adaptation, not invention. Historical examples for creative flair of nations are Korean pottery, tombs and textiles, Chinese script and scripture, Dutch science and medicine, French education, English colonialism, German militarism, and American egalitarianism, corporate efficiency and popular culture (Tobin 1992). The origin of Japanese writing is also from Chinese Kanji characters. Through usage, Japanese were able to adapt the 
difficult kanji characters into easier-to-use characters of their own. It is important to recall that before Japanese were subjected to western influence, they had experienced the same from the Chinese. Chinese words, religion, political ideologies, the well known tea ceremony, silk, poetry, printing, drama, architecture, agriculture, were not something unknown to Japanese.

"...even their most nationalistic writings, including the twelve hundred-year-old "Kojiki" (Record of Ancient Matters), were written in kanji-characters borrowed from the Chinese" (Tobin J J., 1992).

Western products play a key role in social symbolization (conspicuous consumption) among Japanese consumers. At present, learning \& speaking in English, playing tennis or especially golf act as major upward mobility in social class. The Westernization process is not direct. It is "Japanized" by a unique domestication process. Japanese products and foreign products are different in the way they are marketed, advertised and consumed. The distinction starts from Japanese language. They use "wa" to convey the idea of Japanese and " yo" to convey the idea of western. Typically Japanese distinguish local products from those of western origin easily. The food served in western restaurants is referred to as "Yoshoku" and that served in a Japanese restaurant as "shokudo" or "washoku". What is most interesting is that when rice is served in western restaurants it is referred to as "raisu" and but when served in Japanese restaurants it is "gohan".

The Japanese advertising industry played a key role in westernising Japanese consumers. According to Joseph J.Tobin (1992), western models and celebrities are paid highly to present western branded products. These celebrities like George Lucas, Woody Allen, and Faye Dunaway are rarely seen in even in television ads in the United Sates and these performers are featured in Japanese advertising campaigns for drinks, cars and electronic goods. Particularly in advertisements of cars, and American home designs, the appearance of well-known Western models is a common scene. Further, Western models dominate the Japanese advertising of clothes and cosmetics.

\section{METHODOLOGY}

Whilst a major part of this paper is theoretical, a series of in-depth interviews and observations were used to empirically support the theoretical reasoning. One of the authors is residing in Japan and her personal observations, therefore, have been used as a valuable source of qualitative data. The main tool of empirical content is the in-depth 
interviews that were conducted with a selected group of Japanese consumers. Two groups have been used for this purpose. All members could speak and understand English and one of the authors is able to communicate in Japanese and as a result relatively a higher level of reality was captured in the interviews. Most of the members are in their middle ages possessing a wealth of experience regarding changes in culture, society and the purchasing habits over the past 2-4 decades. The respondents in the group consist of individuals who; 1 . live according to traditional culture, 2. have travelled abroad extensively, 3. are pensioners, 4. were career women converted to housewives. All the interviews were tape-recorded and transcribed. Themes and meanings have been extracted to support the reasoning.

\section{INDIVIDUAL CASES - QUALITATIVE ANALYSIS}

In-depth interviews and observations are used to support the argument developed through out the paper. The following themes are used to illustrate the national culture and its role in regulating product choice behaviour.

\section{Traditional Citizen}

Pre-war period signifies the traditional cultural values. Obedience to the hierarchy, extreme loyalty to the authority, wife's devotion to husband, devotion to parents by the children, and devotion to emperor etc.

One respondent commented;

"When we were children, we showed lots of respect to our parents; they made all the purchases. We were brought up in a very traditional cultural environment, we did not see many foreign influence other than the Chinese intervention; we remember a great devotion by our elders to the emperor and to the higher authorities; as I recollect we were a very closed culture with total inward looking nature; our social system was based on a very complex set of mutual understanding and respect"

The "traditional citizen" was loyal and obedient to commands from the hierarchy; in politics, in business, in family matters (parents, children and husband and wife relations) and social relations. Almost all consumption was from indigenous sources.

\section{"National Feeling" and the Formation of High Culture}

The Second World War was a critical incident in solidifying "national" and 
"indigenous" feelings in the minds of the average Japanese. One commented;

"We were led to think that our nation was attacked; some deep feelings of anger and sadness were there; all talked about nation building and the feeling of "us and others" came to our minds; our authorities also influenced us to think this way; we began to develop a feeling of "anti foreign" mentality; we became so closely tight in our culture; however, the economic situation was not good at the time of the war; lots of people were starving and looked for foreign donations of food items; I myself once was in a queue to get a chocolate from US soldiers"

The traditional cultural values together with the national feeling have solidified the high culture that rejects foreign or Western products. This was the time that industrial development and nation building started. The ideas of national redevelopment and economic development had inculcated in the national culture of Japanese. This culture regulated and controlled the purchase decisions. One commented;

"It was our obligation to help national economy; in our purchases too we had this idea of helping our industries; in the beginning the product quality was not good; our economic planners also made people to favour Japanese products by reminding about the cultural values of traditional Japanese."

\section{Enjoyment of Affluence}

The rapid economic development and the emergence of the bubble economy empowered all most all consumers in their buying with more consumer affluence. Consumers matured in selecting products. One side effect of the affluence was the change on cultural values to accept the "outside world". One commented;

\section{Culture and Economy Imbricates with One Another}

Unfavourable economic situation erodes consumer saving and increases consumer spending. Today young single or married couples spend differently than in the past. They spend on betterment of today's life than saving for unpredictable future, which in turn affect seriously on embedded cultural core values. One commented;

"Today my 30 years old daughter earns four times more than what I earned in her age. But unfortunately she spends ten times more than what I spent at that time. I accept the fact that value of a yen is reduced compared with our times. But this excess spending is not merely due to 
that. She doesn't have life expectations as I had. In fact she didn't value them as I did". I notice the same with other young individuals, "shinjinrui", who harvest what we grew in the past, looking for ways to spend their money to enjoy life".

The young Japanese workers lost their expectations due to unfavourable economy. This has become worse when the burden of aged people rests on their heads. They have to pay high taxes with the label of commitment for others benefits, protection of social systems etc. One commented;

"I don't criticize the younger generation as they are heavily burdened with expenses for elders. They lost the meaning of their education and degree earned. They don't see their future clear. It's the nature of youth to seek quick results. We perceived our employment, duty as our life, but they do not".

\section{Shaking High Culture}

Westerners who belong to individualistic cultures, do not value extended families and dependent relations. They believe in democracy, equality and advancement through their own effort. Modern Japanese culture, which lightens "closely knitted "high traditional culture" has begun to show the characteristics of Western culture to some extent. The extended families are disappearing. Modern day Japanese are forced to live in limited space apartment houses, perceiving themselves as independent individuals. Working women are now more independent and enjoy the freedom and equality than what traditional Japanese women experienced. One commented:

"It's very common to see our youth leave their parents soon after they reach adolescence. They find their place of living, part time jobs, earn for their education, find their living partners, they don't care about their parents. There are organizations that look after elders. Women becoming more independent and masculine, those were not present in our time, I stayed at home till I get married, and once I got married I lived with my husband's parents all together".

\section{Threat to Core Values}

The influx of American popular culture with mega performing stars and their songs created a craze in the minds of the young. As a result, they began to seek signs of this pop culture with products like Cola, McDonalds, KFC, etc. The bursting of the bubble economy had threatened the lifetime employment and loyalty to one work place. In 
addition, consumption patterns were forced to change; seeking price advantage over other factors. All these factors taken together have caused a turn in core cultural values. One commented:

"Nowadays, many people (especially young people) begin to criticize and question our cultural values; Its very common to see freelancers, part time workers, who always put their jobs and duties into second place and day to day enjoying life in first place, they are crazy to learn English; American cultural factors are embraced; our food habits too are influenced; with the openness and favourable attitude toward the West, our product selection in shopping has changed lot"

"Our people now easily welcome foreign cultural symbols; this change is reflected in the shopping behaviour too"

\section{Regulation of Culture to Control Purchase Behaviour}

It has been noted that certain influential actions on national culture have taken place, especially from America. The popular culture of USA has infiltrated in to the minds of the younger generation and through that influence, there has been a gradual change in the core Japanese cultural values. Some believe that this process is a conscious process launched as a business and marketing strategy. One reason as to why foreign (US) products did not sell in Japan was that Japanese culture did not favour those products. Therefore, Western marketing strategists attempted to regulate culture to control purchase habits of people. As a result, the high protective culture has been infiltrated. With these changes, Japanese have learned to welcome Western products. The controlling function of culture is evident in this scenario. Some commented:

"We think this American influence is a planned work; our younger generation was carefully witch-crafted by "cultural invasion" with the symbols of American popular culture; mega singers have made a big impact; once people develop a craze to these rituals, they want to live in that by using products that give them the same feeling".

\section{MANAGERIAL IMPLICATIONS AND CONCLUDING COMMENTS}

This paper attempts to explain the controlling function of culture in determining purchase behaviour of consumers in the context of high and low cultures. As the western influence shakes the core values of the Japanese culture, the high culture gradually changes to a low culture. As has been defined, high culture does not welcome what is foreign to a culture. A low culture is a one that is loosely knitted and flexible that 
welcomes what is foreign. The controlling function of culture over the purchase behaviour can be regulated by other factors such as economic condition of the country. Sever inflation and the deterioration of the purchasing power influenced change of attitude toward foreign products. Further, other social consequences of economic problems also influence this process.

Westernization of consumer preferences is derived from the Western influence on the core cultural values. The national culture naturally controls purchase behaviour and therefore by regulating national culture, one can change purchase preferences of consumers to a desired direction. Culture being the software of the mind, has a particular programming pattern that regulate behaviour. Better understanding of the "coding of software" will enable anyone to change the response pattern of the people to a desired level. This paper aims to study as to how a high culture changes over a period of time to accept western values. This process offers important lessons in the way culture can be regulated to control purchase behaviour of group of people.

Japanese believe that their products are high in quality. But at the same time they prefer foreign products, especially American made products. Internationally renowned brands are just as readily accepted by Japanese consumers. For some international brands they are prepared to pay the premium prices even though Japanese products with the same quality are available in the market.

From an organizational perspective, implications of this understanding are important when there is a need for an international market entry strategy. A lucrative, profitable and long-lasting market may not easily welcome a product from another country carrying a cultural identity with it. It is necessary to analyse the core cultural values that prevent the product entering in to the minds of the people. Foreign Companies that target Japanese consumer market have to understand that the target market has a culture of high uncertainty avoidance. They seek accurate information to minimize the perceived risk of buying foreign products. More importantly they belong to a nation with strong nationalistic feelings. Consumers are risk averse. Japanese consumers tend to lower the resistance to foreign products as far as those products comply with product expectations. Unlike independent western consumers, they still expect repect, trust, and responsiveness, politeness, and long-term commitments. By carefully regulating the cultural values, product preferences of consumers can be controlled to the desired level. 


\section{REFERENCES}

Ahmed, Z., and Krohn, F. (1992). Understanding the unique consumer behaviour of Japanese tourists. Journal of Travel and Tourism Marketing, 1 (3), 73-86.

Anderson, P., and Hee, X. (1998). Price influence of age segments of Beijing consumers. Journal of Consumer Marketing.15 (2), 152-69.

Bilkey, W., and Nes, E. (1982). Country of Origin effects on Product Evaluations. Journal of International Business Studies, 13, 89-99.

Brown, D. L. (1996).The Changing Japanese consumers; new attitudes, purchasing behaviour on quality, value and import. East Asian Executive Report, 18(8), 14-16.

Bureau of Tourism Research. (1996). International Visitor Survey, Bureau of Tourism research, Canberra.

Clark, T. (1990).International Marketing and National Character: A review and Proposal for an Integrative Theory. Journal of Marketing, 54, 66-79.

Dentsu Japan .(1988).Marketing/Advertising,163-5.

Deshpande, R., John, U. F., and Frederick, E. W. (1993).Corporate Culture, Customer Orientation, and Innovativeness in Japanese firms: A quadrad Analysis. Journal of Marketing, 57, 23-37.

Douglas., Craig. S. C. (1992).Advances in International Marketing. International Journal of Research in Marketing, 9,291-318.

Elinder, E. (1961).How International Can Advertising be? .International Adviser, 12-16.

Fatt., Arthur. C. (1964). Multinational Approach to International Advertising. International Adviser.17-20.

Gerlach, M.L. (1992).Alliance Capitalism; The Social Organization of Japanese Business. Berkeley, CA: University of California Press.

Hakuhodo Institute of Life and living. (1988).http://www.hakuhodo.co.jp.

Hendry, J. (1987). Understanding Japanese Society. Croom Helm, Beckenham.

Hofstede, G. (1980).Culture's consequence; International Differences in Work related values. Sage Publications, Beverly Hills, CA.

Hall, E.T., and Hall, M. R. (1987).Hidden Differences; Doing Business with the Japanese. Garden City, NY: Anchor/Doubleday.

Hall. Hall, E.T., and Hall, M. R. (1990).Understanding Cultural Differences, Yarmouth. ME: Intercultural Press.

Hall, E T. (1976).Beyond Culture. Doubleday, New York, NY. 
Hofstede, G., (1991). Cultures and Organizations; Software of the Mind. London: McGraw-Hill Book Company (Ltd.).

Itochuo Fashion Systems Co. (1998). Heisei New Family Shouhi Ron (Heisei New Family Consumption Theory). Diamond Publishing, Tokyo.

Johannson, J.K. (1986).Japanese Consumers: What Foreign Marketers Should Know. International Marketing Review, summer, 37-43.

Kajihara, Y. (1990).Changing Pattern of consumer Behaviour and Marketing in Japan: Policy Research Project on Internationalization of Japanese Economy, Nagasaki 850, Japan.

Koester, A.W., and May, J.K. (1985). Profiles of adolescents' clothing practices: purchase, daily selection and care, Adolescense, 20 (77), 97-113.

Krauss, M. (2001).Tech, teens challenge marketers in new ways. Marketing News, 35(9), 10.

Levitt, T. (1983). The Globalization of Markets. Harvard Business Review, 61, 92102.

Leiper, N. (1985).The Japanese Travel Market and Its potential for Australian Tourist Destinations. Qantas Airways Ltd, Sydney.

Leiper, N. (1987).The Japanese Travel Market and Its Potential for Australian Tourist Destinations. Qantas Airways Ltd.Sydney.

Meredith, G.E., and Schewe, C.D. (2002).Defining Markets, Defining movements: America's Seven Generational Cohorts, Their Shared Experiences, and why Business Should Care, 7, John Wiley \& Sons, New York, NY.

McCreery, J. (2000).Japanese Consumer Behaviour.Curzon Press, Richmond.

Money, B. R.,Gilly, C. M.,\& Graham, L. J.(1998).Explorations of National Culture and Word -of-Mouth Referral Behaviour in the Purchase of Industrial Services in the United States and Japan. Journal of Marketing, 62, 76-87.

Netermeyer, R., Durvasula, S., and Lochtenstein, D. (1991), A cross-national assessment of the reliability and validity of the CETSLALE.Journal of Marketing Research, 28,320-327.

Ogawa, S. (1988). Innovations of the Convenience -store Ordering System in Japan, Japanese Distribution Strategy. TJ International and UK.

Ohmae, K. (1985).Trade Power: The Coming Shape of Global Competition. New York, The Free Press.

Parker, R.S., Herman, C, M., and Schaefer, A .D. (2004).Fashion consciousness of 
Chinese, Japanese and American teenagers. Journal of Fashion Marketing and Management, 8(2).

Rierson, C. (1967).Attitude Changes toward Foreign Products. Journal of Marketing Research, 4,385-387.

Roth, M. (1995).The effects of Culture and Socioeconomics on the performance of Global Brand Image Strategies. Journal of Marketing Research, 32,163-75.

Roostal, I. (1963).Standardization of Advertising for Western Europe. Journal of Marketing, 27, 15-20.

Samiee, S. (1994).Customer evaluation of Products in a global Market. Journal of International Business Studies, Third quarter, 579-604.

Sansom, G.B. (1931).A short cultural History. Tokyo: Tuttle, Japan.

Shimp, T A, and Sharma, S. (1987). Consumer Ethnocentrism; construction \& Validation of the CETSCALE. Journal of Marketing Research, 12,317-326.

Social Indicators. (1997). Statistics Bureau Management and coordination Agency. Tokyo, Japan.

Shin, S., Gehrt, K., and Lotz, S. (2001).Export Implication for the Japanese fruit market; Fruit Specific life Style Segments. International Journal of Retail and Distribution Management, 29(6), 298-314.

Sullivan, J., and Richard, B.P. (1988).Factors Associated with Trust in JapaneseAmerican Joint ventures. International Management Review, 22(2), 30-40.

Swanson, J. (2005).Recognition and Redistribution: Rethinking Culture and Economics, Theory, Culture \& Society (pp.87-118).SAGE, London, Thousand Oaks and New Delhi.

Tobin, J. J. (1992). Remade in Japan. Vail -Ballou Press, New York.

Turcq, D., and Usunier, J. C. (1985). Les services au Japan: I'efficacite...par la nonProductive Revue Freancaise de Gestion, May-June, 2-15.

White.(1993).The Material child coming of age in Japan and America. The Free Press, New Yourk, NY, p.256.

Wysock, B. (1997).The Global mall: in Developing Nations, may youths splurge; mainly on US goods-flush with cash and plastic, they load up on Levi's and tune in to MTV-a lot of "Little Emperors. The Wall Street Journal, (Eastern Edition) 26 (June), p.A1.

Ziff-Levine, W. (1990). The cultural logic gap: a Japanese tourism research experience, Tourism Management, 11(2), 105-10. 
Zimmerman, M. (1985). How to Do Business with Japanese: A strategy for Success. Random House and New York, NY. 